\title{
Pembinaan Masyarakat Tentang Komersialisasi Dan Sterilisasi Industri Pada Pengolahan Abon Ikan Tongkol
}

\author{
Citra Indah Asmarawati*1 \\ 1Program Studi Teknik Industri, Fakultas Teknik dan Komputer, Universitas Putera Batam \\ *e-mail: citraasmarawati93@gmail.com ${ }^{1}$
}

\begin{abstract}
Abstrak
Pengabdian kemitraan masyarakat ini bertujuan untuk meningkatkan produktivitas dan income masyarakat dengan pemberdayaan ekonomi kerakyatan dan pendampingan Usaha kecil menengah dengan stimulant keterampilan di bidang teknologi dan pengelolaan higiyenisasi produksi abon ber merk "Sari Abon" di kelurahan tanjung Buntung kecamatan Bengkong. Tahapan langkah pelaksanaan program pengabdian masyarakat ini diawali dengan pendekatan terpadu yang dilakukan dari proses awal sosialisai dan rencana selama kegiatan berlangsung secara efektif kurang lebih 3 bulan. Pada sosialisasi awal, tim mengundang para pekerja yang terlibat pada proses pembuatan abon ikan untuk menyosialisasikan kegiatan yang dilaksanakan agar terjadi komunikasi yang efektif dan timbal balik. Pembinaan yang akan dilakukan oleh pengabdi akan dilanjutkan dengan pengelolahan pengolahan abon ikan tongkol "Sari Abon" menjadi lebih baik dengan melakukan peningkatan kualitas produk dan pemasaran yang dilakukan dari pemilik dan juga menambah memperbaiki sisten manajemennya. Produk abon akan memiliki label sendiri dan kemudian akan dipasarkan melalui platform e-commerce.
\end{abstract}

Kata kunci: Abon Ikan, Ikan Tongkol, UMKM

\begin{abstract}
This community partnership service aims to increase the productivity and income of the community by empowering the people's economy and mentoring small and medium enterprises with stimulant skills in the field of technology and hygienic management of shredded production with the brand "Sari Abon" in tanjung Buntung sub-district, Bengkong district. The stages of implementing this community service program begin with an integrated approach carried out from the initial socialization process and plan during the activity to take place effectively for approximately 3 months. At the initial socialization, the team invited workers involved in the process of making fish floss to socialize the activities carried out so that effective and reciprocal communication could occur. The guidance that will be carried out by the servants will be continued with the management of the processing of tuna shredded "Sari Shredded" for the better by improving the quality of products and marketing carried out by the owner and also improving the management system. Shredded products will have their own label and will then be marketed through e-commerce platforms.
\end{abstract}

Keywords: Tuna Fish, Tuna Floss, UMKM

\section{PENDAHULUAN}

Pembinaan terhadap industri kecil mulai digalakkan terutama di bidang makanan untuk meningkatkan kebutuhan masyarakat akan asupan protein dalam kesehariannya.pengabdian kepada masyarakat ini mengambil lokasi pada produksi rumahan abon siap hidang dengan merk Sari Abon yang berlokasi di komplek PBN blok B11, Tj Buntung Kec Bengkong, Batam. Usaha ini baru dirintis belum genap setahun yaitu pada bulan juli 2019. Proses pengolahan bahan mentah hingga pengelolaan pemasaran belum dilaksanakan secara memadai. Proses pembuatan masih sederhana dan proses higienisasi masih belum sempurna.

Pembinaan terhadap industri kecil mulai digalakkan terutama di bidang makanan untuk meningkatkan kebutuhan masyarakat akan asupan protein dalam kesehariannya.pengabdian kepada masyarakat ini mengambil lokasi pada produksi rumahan abon siap hidang dengan merk Sari Abon yang berlokasi di komplek PBN blok B11, Tj Buntung Kec Bengkong, Batam. Usaha ini baru dirintis belum genap setahun yaitu pada bulan juli 2019. Proses pengolahan bahan mentah hingga pengelolaan pemasaran belum dilaksanakan secara memadai. Proses pembuatan masih sederhana dan proses higienisasi masih belum sempurna. Sebagian besar kelurahan Tanjung Buntung terletak di pesisir laut hal ini membuat sebagian besar masyarakat sekitar bermata 
pencaharian sebagai nelayan dan potensial mengembangkan berbagai macam produk makanan berbahan dasar ikan, seprti abon ikan [1]. Abon merupakan produk pangan yang terbuat dari daging ikan yang yang dipisahkan antara serat dan tulang yang kemudian dilakukan penghalusan dengan menggunakan teknik penggorengan secara lepas. Proses secara sederhana biasanya ditambahkan bumbu-bumbu dan sedikit bahan alami agar lebih awet dan tahan lama ketika dipasarkan ke masyarakat [2]. Selain itu, abon ikan baik digunakan oleh semua kalangan karena banyak gizinya, terutama anak-anak yang masih dalam masa pertumbuhan dan baik untuk perkembangan otak karena mengandung protein tinggi, Omega 3, Omega 6, dan rendah kolesterol [3].

\section{METODE}

Pelaksanaan kegiatan pengabdian masyarakat ini dimulai dari proses pendekatan terpadu yang dilaksanakan mulai proses awal sosialisasi hingga rangan kegiatan yang akan dilaksanakan secara efektif sekitar 3 bulan. Untuk proses sosialisasi awal tim pengabdi akan mengundang para pekerja yang melaksanakan proses pembuatan abon ikan untuk menyosialisasikan kegiatan yang akan dilakukan supaya terlaksanakan komunikasi yang efektif dan dapat memberikan feedback.Metode yang dipakai untuk kegiatan pengabdian ini berupa training of trainer (TOT) dimana selain memparkan materi, tim pengabdi juga meberikan pendampingan kepada mitra[4].

Untuk melaksanakan keseluruhan kegiatan dilakukan menggunakan 2 jenis metode yaitu sosialisasi dan diskusi[5]. Sosialisasi ini dilakukan melalui pemberian materi kepada mitra yang berekerjasama agar mampu mengatasi permasalahan yang selama ini menjadi kendala yang menghambat kinerja mintra. Materi yang diberikan diharapkan mampu menambah pengetahuan juga mampu diaplikasikan dalam kegitan usaha milik mitra.

Usai bahan materi diberikan, kemudian kegiatan selanjutnya berupa diskusi berupa sesi tanya jawab yang dilakukan oleh pemateri dan juga peserta yang hadir. Kegiatan diskusi ini dilaksanakan supaya mengetahu sejauh mana pemaham materi yang diterima oleh peserta yang hadir. Pada kegiatan diskusi ini akan terjadi sharing ilmu dan juga sharing pengalaman atau permasalahn apa saja yang dimiliki oleh mitra.

Produk abon ikan tongkol akan dikemas dan diberikan label. Label ini akan berfungsi untuk memberikan informasi juga menjadi merek dari produk abon ikan tongkol. Pemberian label ini nantinya akan memudahkan produk untuk dipasarkan melalui media pemasarannya yaitu platform e-commerce shopee ataupun pada saat nanti dipasarkan melalui beberapa minimarket.

Tabel 1 Metode Kegiatan Pengabdian Masyarakat

\begin{tabular}{clcc}
\hline No. & \multicolumn{1}{c}{ Heading } & Heading \\
\hline 1 & $\begin{array}{l}\text { Penyuluhan tentang komersialisasi dan } \\
\text { peningkatan pemasaran }\end{array}$ & Ceramah \\
2 & $\begin{array}{l}\text { Strategi memaksimalkan pemasaran online } \\
\text { produk makanan olahan }\end{array}$ & Ceramah dan diskusi \\
3 & $\begin{array}{l}\text { Penciptaan Branding dan solusi } \\
\text { permasalahan UKM } \\
\text { Mekanisme strategi pemasaran guna } \\
\text { peningkatan penjualan barang dan jasa }\end{array}$ & Ceramah dan diskusi \\
4
\end{tabular}

\section{HASIL DAN PEMBAHASAN}

Seiring dengan perkembangan waktu, teknologi pengolahan makanan saat ini telah berkembang pesat. Produsen telah menggunakan beberapa teknologi seperti halnya metode penggorengan, bahan tambahan makanan, bahan pengawet, bahan pewarna dan sebagainya pada produk makanan dan minuman. Komunikasi antara produsen dan konsumen perlu dikembangkan dengan pencantuman label dan sertifikasi yang dimiliki. Pencantuman labelisasi 
dan sertifikasi serta informasi nilai gizi pada produk atau kemasan merupakan tidak hanya sebagai bentuk komunikasi semata, melainkan juga upaya perlindungan terhadap konsumen. Sebagai contoh labelisasi dan sertifikasi halal menjadi sebuah jaminan konsumen terhadap kehalalan produk tersebut. Informasi nilai gizi memperlihatkan kandungan dan asupan gizi yang ada dan dapat dimanfaatkan untuk kesehatan.

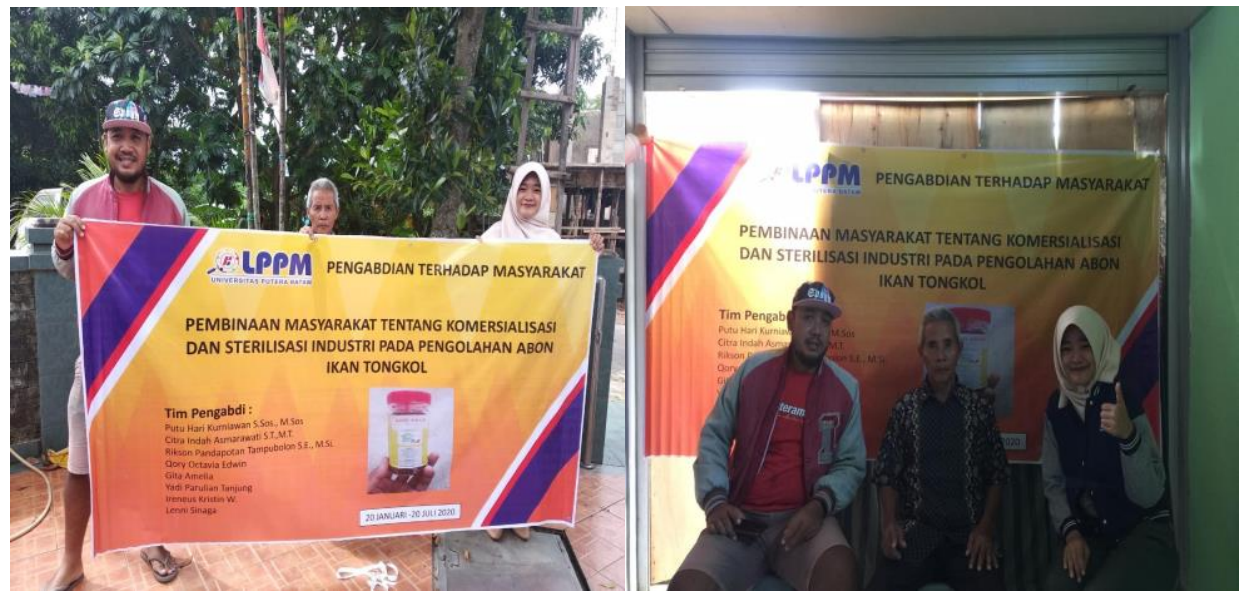

Gambar 1. Kegiatan Pengabdian Abon Ikan

Sosialisasi labelisasi produk dilakukan diskusi mendalam dengan mitra. Secara individudan kelembagaan usaha, mitra sangat memahami pentingnya labelisasi produk yang dihasilkan dandipasarkan baik sertifikasi yang dimiliki, komposisi dan sebagainya. Mitra berkomitmen untukmenerapkan dalam produknya, sekaligus meningkatkan branding produk mereka sendiri.

Label ini dibuat dengan cara memilih merk dan desian label yang dibuat sedmikian rupa agar mampu menarik perhatian konsumen dan menjadi identitas dari produk. Dalam label akan berisi nama produk, kandungan, cara penyimpanan dan masa penggunaan produk.
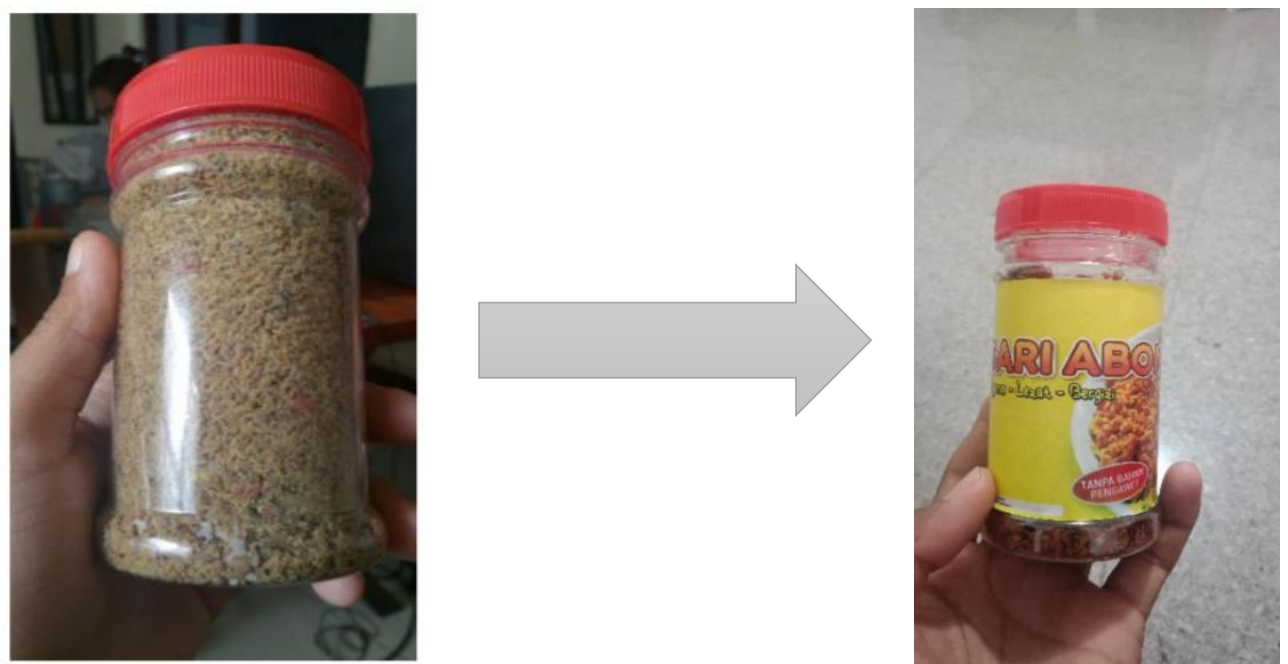

Gambar 2. Labelling Abon Ikan Tongkol "Sari Abon”

Produk Sari abon biasanya dipasarkan diminimarket tertentu saja. Melihat era digital yang semakin pesat produk sari abon juga akan dipasarka melalu beberapa e-commerce yaitu Shopee. Sehingga produk "Sari Abon" ini dapat dipasarakan lebih luas dan dapat menjangkau konsumen diseluruh Indonesia.

Pembinaan yang akan dilakukan oleh pengabdi akan dilanjutkan dengan pengelolahan pengolahan abon ikan tongkol "Sari Abon" menjadi lebih baik dengan melakukan peningkatan kualitas prroduk dan pemasaran yang dilakukan dari pemilik dan juga menambah memperbaiki 
sisten manajemennya. Hal ini dapat di tindak lanjuti, karena pengusaha pengolahan abon ikan tongkol "Sari Abon", juga mendukung program pengabdian ini.

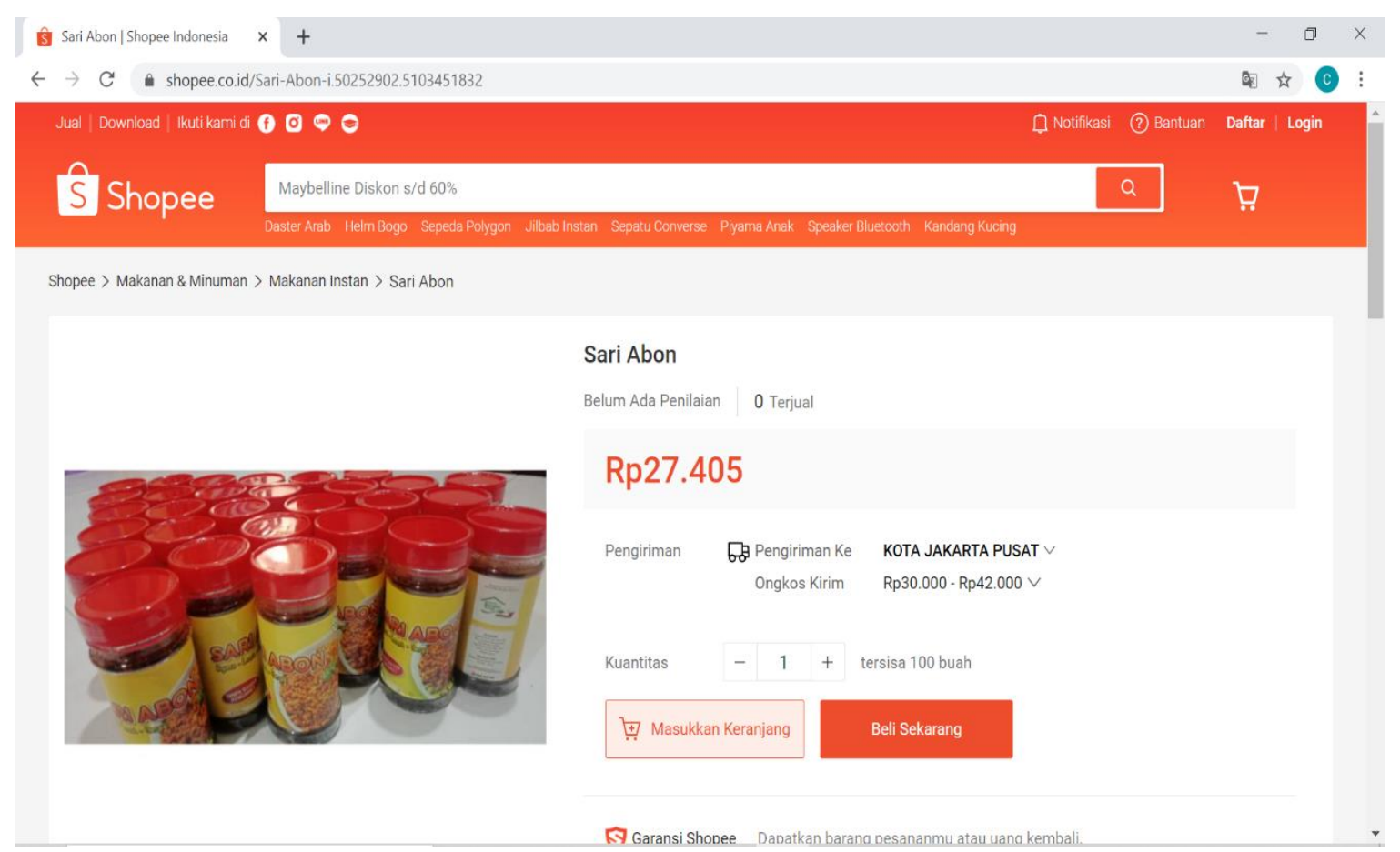

Gambar 3.Pemasaran Abon Ikan Menggunakan E-Commerce

Dengan dilakukannya kegiatan pengabdian kepada masyarakat ini ada beberapa manfaat yang diperoleh dari kegiatan tersebut diantaranya ialah:

1. Membangun dan terciptanya hubungan serta kerjasama yang baik antara pihak Universitas Putera Batam dengan mitra dalam hal ini pemilik usaha "Sari Abon".

2. Meningkatnya pengalaman kepada tim pengabdi dalam memberikan dan menyampaikan materi pengabdi khusus nya tentang pembibitan komersialisasi dan sterilisasi pada abon ikan

3. Menambah informasi dan ilmu pengetahuan bagi pemilik usaha "Sari Abon".

4. Pemilik usaha (mitra) mengetahui pentingnya pemasaran menggunakan E-Commerce.

5. Meningkatkan pendapatan pemilik usaha "Sari Abon" melalui metode pengelolaan keuangan yang baik.

\section{KESIMPULAN}

Melalui kegiatan pengabdian masyarakat pada usaha pengolahan abon "Sari Abon" yang telah dilaksanakan dapat disimpulkan bahwa pengetahuan mengenai bagaimana pengolahan abon ikan tongkol dapat ditingkatkan serta Abon Ikan Tongkol "Sari Abon" telah dipasarkan menggunakan Platform E-commerce Shopee.

\section{UCAPAN TERIMA KASIH}

Penulis mengucapkan terima kasih kepada Putu Hari Kurniawan S.Sos., M.M. yang telah memberi dukungan terhadap pengabdian ini. Dukungan yang diberikan mulai dari pendampingan hingga bantuan secara finansial demi kelancaran pengabdian ini. 


\section{DAFTAR PUSTAKA}

[1] R. S. Sundari and D. S. Umbara, "PREFERENSI KONSUMEN TERHADAP PRODUK AGROINDUSTRI ABON IKAN," J. MEBIS (Manajemen dan Bisnis), vol. 4, no. 1, pp. 36-43, 2019, doi: 10.33005/mebis.v4i1.51.

[2] R. Aliyah, I. Gumilar, and I. Maulina, "Strategi Pengembangan Usaha Pengolahan Abon Ikan (Studi Kasus Rumah Abon Di Kota Bandung)," J. Perikan. dan Kelaut. Unpad, vol. 6, no. 2, 2015.

[3] I. T. Setiawati and S. Ningsih, "Manajemen Usaha Pengolahan Abon Ikan Lele (Clarias gariepinus) di P2MKP Jaya Mandiri Kecamatan Bulu, Kabupaten Temanggung," J. Penyul. Perikan. dan Kelaut., vol. 12, no. 2, pp. 95-110, 2018, doi: 10.33378/jppik.v12i2.103.

[4] P. E. Septiani, "Jurnal Pengabdian Masyarakat," Din. J. Pengabdi. Kpd. Masy., 2019, doi: 10.31849/dinamisia.v3i1.2729.

[5] I. Efendi, I. N. Dewi, S. D. Utami, B. M. Harisanti, and S. N. Primawati, "Jurnal Pengabdian UNDIKMA:," J. Has. Pengabdi. Pemberdaya. Kpd. Masy., 2020. 